\title{
Khouribga a sprawa polska. Zwycięstwo życia nad kulturą w pisarstwie Fouada Larouiego
}

Ewa Łukaszyk

TEKSTY DRUGIE 2018, NR 4, S. 297-309

DOI: $10.18318 /$ td.2018.4.18

W debacie nad studiami postkolonialnymi w Polsce czy też Polską, jaka mogłaby się ukazać naszym oczom dzięki postkolonialnym narzędziom pojawił się ostatnio nurt rozliczenia ze specyficzną formacja, jaka zaistniała pod internacjonalistycznym patronatem Bloku Wschodniego. W takim kierunku idzie m.in. niedawna książka Adama Koli Socjalistyczny postkolonializm. Rekonsolidacja pamięci, gdzie stawką jest przeprowadzenie analizy praktyk Drugiego Świata (i rekonsolidacja zacierającej się pamięci o nich i o roli,jaką odegrały w polskich losach indywidualnych izbiorowych)'. Powinno to doprowadzić nie tylko do krytycznej oceny neokolonialnej roli, jaką odegrały kraje uwikłane w sowiecką ekspansję, usiłującą wcisnąć się w miejsca opuszczone przez zachodnioeuropejskich kolonizatorów, przede wszystkim w różnych miejscach Afryki i Bliskiego Wschodu, ale i naświetlenia pewnej cząstki polskiego losu w powiązaniu ze światem.

1 Por. A. Kola Socjalistyczny postkolonializm. Rekonsolidacja pamięci, Wydawnictwo UMK, Toruń, 2018.
Ewa Łukaszyk - dr hab., komparatysta i krytyk kultury; dawniej związana z Uniwersytetem Jagiellońskim i Warszawskim, obecnie pracuje za granicą.

Definiując kondycję transkulturową jako jakościowo odrębny stan bytowania człowieka, leżący ponad sferą kulturowych automatyzmów, rozwija projekt „Poetyki pustki", dotyczący świadomego zrywania ciągłości kulturowych granic i wzorców w Środziemnomorzu. 
Kola wychodzi od lektury dokumentów, jakie można bez trudu odnaleźć w magazynach polskich bibliotek, powstałych wokół takich wydarzeń, jak chociażby Światowy Kongres Intelektualistów w Obronie Pokoju we Wrocławiu w 1948 roku, i wytworzonej w tych okolicznościach dyskursywnej tradycji. Tłumaczone - jak omawiana przez Kolę broszura Grigorija Akropiana W.I.Lenin iJW. Stalin o ruchu narodowo-wyzwoleńczym narodów kolonialnych izależnych ${ }^{2}$ - czy też tworzone na miejscu, teksty programowe głoszące wiodącą rolę bloku w kształtowaniu losu tych narodów ustanowiły wyobrażoną lokalizację Polski na świecie i podyktowały, braną mniej lub bardziej na poważnie, wyzwolicielską misję, domniemane zobowiązanie wobec odległych ludów, których istnienie i realia rysowały się nader mgliście w polskiej świadomości. Stoję na stanowisku, bez wątpienia kontrowersyjnym i dla wielu osób wręcz oburzającym, że polska ślepota wobec świata utrzymuje się aż do dnia dzisiejszego. Mimo oczywistych postępów akademickiej wiedzy o świecie, natężenia ruchu translatorskiego, a nawet częstotliwości i prestiżu symbolicznego, jaki łączy się w polskiej kulturze potocznej z zagranicznymi wojażami, zarówno tymi wyłącznie turystycznymi, jak i noszącymi znamiona ambitnych wypraw podróżniczych, świat oglądany z polskiej perspektywy rysuje się nadal w kategoriach egzotycznych, a więc, w etymologicznym sensie, jako coś zewnętrznego, leżącego poza orbitą naszych własnych spraw. Stąd też potrzeba rekonsolidacji, nie tylko pamięci, ale i obrazu świata jako obszaru powiązanego z polskim losem.

Wobec problemu niepamięci, na jaki słusznie wskazuje Kola, istotne wydaje się odebranie specyficznej przesyłki zwrotnej, jaka została co prawda wysłana nie na nasz, lecz na francuski adres, lecz tą okrężną drogą zapewne musi wcześniej czy później do nas dotrzeć3. Kilkudziesięciostronicowa nowela Fouada Larouiego Les noces fabuleuses du Polonais [Wspaniałe zaślubiny Polaka], zawarte w tomie pod tym samym tytułem, wydanym w 2015 roku $^{4}$, wnosi frapujący wkład w rozważania nad polską „postkolonialnością” (dalszy ciąg wywodu uzasadni wzięcie tego pojęcia w cudzysłów).

2 Tamże, s. 86-93.

3 Jak do tej pory Fouad Laroui wydaje się pisarzem w Polsce zupełnie nieznanym; katalog biblioteki Uniwersytetu Warszawskiego informuje wyłącznie o dostępności francuskojęzycznych egzemplarzy dwóch powieści tego skądinąd poczytnego na Zachodzie autora. Przeświadczenie o popularności Larouiego, jak również niniejszy artykuł, jest rezultatem mojego pobytu we Francji.

Por. F. Laroui Les noces fabuleuses du Polonais. Nouvelles, Julliard, Paris 2015. 
Fouad Laroui, dzisiaj profesor literatury Uniwersytetu w Amsterdamie, autor kilkunastu powieści i zbiorów opowiadań napisanych po francusku, jak również poezji w języku niderlandzkim, urodził się w 1958 roku w marokańskiej Oujdzie, mieście położonym na wybrzeżu, przy algierskiej granicy, i rzeczywiście pracował kiedyś jako inżynier w wielkim kombinacie produkcji fosfatów w miejscowości Khouribga, położonej 120 kilometrów na południe od Casablanki; Le noces fabuleuses du Polonais noszą więc szczególne rysy niemal dokumentalistycznego realizmu. Rzecz dzieje się w zamierzchłych latach osiemdziesiątych, a bohater, Matchek, czy też - jak się później dowiadujemy, Maciej - jest dentystą „na kontrakcie”, przybyłym do kombinatu wraz z grupą innych polskich specjalistów.

W taki czy inny sposób, Polacy okazują się kontynuatorami kolonialnej historii, chociażby przez odmowę bliskich kontaktów z tubylcami, z którymi porozumiewają się, wyłącznie w ściśle zawodowych okolicznościach, za pomocą rudymentarnej angielszczyzny i raptem setki francuskich słówek. Matchek wyłamuje się jednak z tej grupy ze względu na niemal etnologiczne zacięcie; z zeszycikiem do słówek w ręku, przyswaja sobie miejscowy dialekt, dariję. Pozostali Polacy reagują na to marginalizacją ekscentrycznego stomatologa; jak pisze Laroui, „pewnie przynosił im wstyd tym, że się tak mieszał z lokalnym plebsem"'. Co więcej, Matchek staje się też figurą komiczną w miejscowym środowisku i naraża się na swoisty odwet kolonizowanego - zorganizowane z dużym rozmachem oszustwo. Marokańczycy oszukują jednak Polaka w dużej mierze na jego własne życzenie, skoro to od niego pochodzi - skądinąd znany i popularny u nas swego czasu - pomysł ślubu zaaranżowanego dla żartu. Jak nietrudno się domyśleć, jego konsekwencje okazują się najzupełniej poważne.

Zatrzymajmy się jednak przy roli Polaków jako nowych kolonizatorów, mających nadać ciągłość porzuconej przez Francuzów mission civilisatrice. Przede wszystkim Polacy nie przyjmują do wiadomości ich odejścia i końca kolonialnej epoki. Matchek jest szczerze przekonany, że dyrektor kombinatu (wewnątrztekstowy Laroui we własnej osobie) nie może być rodowitym Marokańczykiem, gdyż Francuzi nigdy by nie pozwolili, by ktoś taki kierował największą kopalnią w kraju. Podobnie „, bardzo słabo zorientowany w historii" („très peu versé en histoire”) ${ }^{6}$ jest polski ginekolog, kolejna z kluczowych postaci w tym opowiadaniu, przekonany, że Maroko nadal stanowi francuski

\footnotetext{
5 Tamże, s. 15-16.

6 Tamże, s. 11.
} 
protektorat. Co więcej, ta szczególna ślepota Polaków wyklucza lustrzane odbicie i odczytanie wiadomości zwrotnej, a mianowicie sugestii, że ich własny kraj stanowi protektorat sowiecki, co w tej epoce było przecież przynajmniej do pewnego stopnia prawdziwe. Tych lustrzanych odbić znalazłoby się zresztą więcej, chociażby w sposobie traktowania kobiet, które polski ginekolog i nie tylko on - postrzega wyłącznie jako ciała.

Mimo pozornej nierównoważności wspomagających kraj Trzeciego Świata specjalistów i otrzymujących tę pomoc tubylców, w gruncie rzeczy w tej historii spotykają się, w różnych wymiarach, wyłamujące się spod kurateli protektoraty i ich zależni mieszkańcy, cierpiący z powodu różnorakich niedostatków i braków. Tylko ich całkowita ślepota na siebie nawzajem tworzy komiczny wymiar opowieści. Egzotyczne - jak odnotowuje Laroui - jest dla Polaków nie tylko Maroko, ale i Coca-Cola, napój w ówczesnej Polsce niedostępny, a stanowiący tutaj ośrodek swoistego rytuału wspólnego picia, łączący Matchka z robotnikami. Wreszcie ostatnim z niedostępnych rytuałów egzotycznych okazuje się marokański ślub, który Matchek pragnąłby zobaczyć na własne oczy. Niestety analiza miejscowych stosunków szybko pozwala się upewnić, że tego rodzaju uroczystość nie wydarzy się w miasteczku jeszcze przez wiele miesięcy. Stąd pomysł aranżacji wesela na niby, specjalnie po to, by Matchek mógł je zobaczyć. Co go w dużej mierze zaskakuje, ma to być wesele z nim samym w roli głównej. Uroczystość poprzedza nie mniej żartobliwa konwersja na islam, w której Polak, wciąż źle sobie radząc z językiem, deklaruje swą niezłomną wiarę w to, że Mahomet jest wysłannikiem Layli.

Jedynym smutnym akcentem ceremonii, której uczestnicy niemal od początku do końca tarzają się ze śmiechu, jest postać panny młodej, której uczernione na tę okoliczność oczy okazują się „tyleż czarujące, co melancholijne”. Kobieta, przyniesiona z hammamu w lektyce niemal jak bezwładne ciało, z pozoru siłą tejże bezwładności pozostaje w willi, którą Polak, jako nowy realizator mission civilisatrice, odziedziczył po francuskich poprzednikach. A jednak zachodzi tu znacząca zamiana miejsc, niemal na zasadzie Bachtinowskiej karnawalizacji. Matchek zresztą już wcześniej uległ przemianie, z szanowanego i cenionego dentysty przeistaczając się w komicznie przekręcającego słowa, miejscowego błazna. W świecie, którego porządek został wywrócony na opak, ten nowy kolonizator z Drugiej Europy staje się kolonizowanym; jak na Bachtinowską logikę przystało, dzieje się to za sprawą brzucha. Już 
całe sfingowane wesele było przede wszystkim jedną wielką ucztą, pozwalającą Marokańczykom nasycić się za pieniądze Polaka; następująca po niej noc poślubna prowadzi do dalszego zaokrąglenia brzucha. Wreszcie panna młoda na niby przełamuje swój niepoważny status dzięki temu, że karmi Matchka marokańskim jedzeniem w sposób pod każdym względem doskonały (erotyczny i na swój sposób inicjacyjny wymiar tego karmienia miesza się w scenie, gdy Matchek po raz pierwszy kosztuje amlou, oleju arganowego zmieszanego z migdałami i orzechami). Po przyjściu na świat dwójki dzieci karnawałowa historia małżeństwa Polaka zostaje tymczasowo zamknięta.

Nowa sekwencja tekstu otwiera historię bynajmniej nie karnawałową, w której streszczają się dotychczasowe losy Daouii. Córka ubogiego człowieka z samego dołu miejscowej hierarchii już jako nastolatka została wydana za mąż za pewnego Marokańczyka pracującego we Włoszech. Pomówienie o zbyt bliskie kontakty z mężczyznami (mężczyzną owym miał być chłopak przypadkowo spotkany w parku) prowadzi do rozwodu i usunięcia z domu krewnych emigranta, w którym urodziwa dziewczyna odgrywała zresztą rolę Kopciuszka wśród brzydkich sióstr zaledwie parokrotnie widzianego męża. Daouia jest otoczona złą famą jako niemal kobieta lekkich obyczajów, toteż drugi mąż trzyma ją pod kluczem w przykopalnianym mieszkaniu. Interwencja przełożonego, podyktowana troską o przepisy pożarowe, prowadzi jedynie do nowego rozwodu. Toteż błazeńskie małżeństwo z Polakiem z pozoru w niczym już nie może pogorszyć jej położenia, a do wygrania pozostaje zawsze możliwość zamieszkania w postkolonialnej willi.

Daouia z pewnością nie weszła do tego małżeństwa jako autonomiczna jednostka; z kolei Matchek w swojej karnawałowej trajektorii uległ czarowi dolnej połowy jej ciała, mianowicie mięsistym pośladkom, jakie ujrzał, wracając do domu, gdy młoda żona czyściła ogrodową pergolę. Dzięki wytworzonej przez drabinę różnicy poziomów to nie z jej twarzą się spotkał, lecz z jej pupą. Nic nie wskazuje na to, by był gotów do roli wyzwoliciela reprezentantki „narodów zależnych”, czy to od protektoratu kolonialnego, czy też od lokalnego jarzma patriarchatu; od żadnego z tych zjawisk sam nie był do końca wolny. A jednak poza granicą diegezy, jakimś cudem - Opatrzność (bez uściślenia religii, z jaką miałaby się wiązać) zostaje przywołana na koniec jako ukryty motor zdarzeń - następuje wyzwolenie kobiety od lokalnej tyranii i narzuconego jej niegdyś statusu ofiary. Przemiana zostaje zasygnalizowana zmianą jej imienia: Daouia na jakimś etapie stała się Marią. O dokładnych okolicznościach niczego się nie dowiadujemy. Narrator, dawny dyrektor kombinatu, spotyka po latach tylko Adama i Hannę, dwójkę dzieci Macieja i Marii, 
które, jak się domyśla, muszą być właśnie tymi, które urodziły się niegdyś z błazeńskiego związku polskiego dentysty. Nie należą ani do Maroka, ani do Polski; są świetnie zapowiadającymi się młodymi Francuzami u progu kariery w finansach (Adam) i dyplomacji (Hanna). Upłynnione przez karnawałową transformację granice, obyczajowe reguły czy etniczne tożsamości gdzieś po drodze wyblakły i znikły zupełnie. A przecież Matchek chciał ich wychować na Polaków i uczył francuskiego jedynie w hołdzie dla Clemenceau, który jak wzmiankuje Laroui w przypisie, na konferencji pokojowej w 1919 roku miał wnieść swój przyczynek do sprawy polskiej. Również w tym przypadku gdzieś po drodze musiała nastąpić zmiana, o której okolicznościach niczego się nie dowiadujemy. Oglądamy tylko rezultat końcowy, podwójny owoc mieszanego małżeństwa wyróżniający się fizyczną pięknością i kroczący w stronę świetlanej, niczym nie skrępowanej i pozbawionej kompleksów przyszłości.

Opowiadanie Larouiego z pewnością może posłużyć jako przypomnienie pewnej zapomnianej cząstki polskich losów, choćby była tak z pozoru nieznacząca i nie zmieniała biegu historii jak „eksportowe kontrakty” z lat 80. Pozwala zarysować kontury „postkolonialności” polskiej - właśnie takiej, wziętej w cudzysłów, karnawałowej, nieświadomej własnej roli i miejsca w dziejach, jak w przypadku owego ginekologa, który mniemał, że Maroko jest nadal francuskim protektoratem, spóźniając się w stosunku do biegu historii co najmniej o ćwierćwiecze ${ }^{8}$. Dzisiaj jej akademickie rozważanie, spóźnione nadal o ćwierćwiecze w stosunku do czasów, w których teoria postkolonialna się rozwijała i odgrywała istotną rolę w humanistyce światowej, wydaje się skupiać na głosach i materiałach dostępnych lokalnie, bez oczekiwania na przesyłkę zwrotną ze świata. Jak się wydaje, polscy zwolennicy studiów postkolonialnych nie spodziewają się i nie poszukują - lub poszukują nie dość usilnie - obcej opowieści o nas samych. A na tym przecież studia postkolonialne w klasycznym rozumieniu się opierały.

O ile zdarzyło mi się dotychczas zabrać głos w polskiej debacie wokół kwestii postkolonialnych, rozczarowywałam zwykle dyskutantów natrętnym przywoływaniem anachronizmu kryjącego się w uporczywym wracaniu do tej teorii w czasach jej zmierzchu, za cenę samowykluczenia z aktualnych nurtów

8 Maroko stało się protektoratem francuskim na mocy traktatu zawartego w 1912 roku w Fezie z sułtanem Abdelhafidem; kres tego okresu historii został zapowiedziany przez sułtana Muhammada ben Jusufa - późniejszego króla Muhammada V - w listopadzie 1955, a uznany oficjalnie również przez stronę francuską 2 marca 1956 roku. 
humanistyki światowej ${ }^{9}$. I w dalszym ciągu, przywołując w niniejszym tekście nowelę Larouiego, co więcej, określając ją za pomocą znanej metafory przesyłki zwrotnej, nie pragnę bynajmniej do studiów postkolonialnych powrócić. Przesyłka Larouiego nie tylko trafia, jak już wspomniałam, pod zupełnie inny adres, lecz przede wszystkim jest już zupełnie czym innym niż „odpisujące imperium" z klasycznej pracy Ashcrofta, Griffithsa i Tiffin ${ }^{10}$. Przesłanie pisarza dotyczy już czegoś innego, a mianowicie ostatecznego rozpłynięcia się granic, erozji murów, jakie więziły człowieka zarówno w kolonialnych, jak i postkolonialnych realiach. Właśnie dzięki temu - z głupich żartów, jakimś cudem, może dzięki Opatrzności, która jest tu po prostu metaforą chaosu zdarzeń w nieuchronnie toczącym się czasie - Daouia wychodzi na wolność zza murów marokańskiego patriarchatu. Dekolonialny delinking, by użyć terminu ukutego przez Waltera Mignolo"11, rozprzęgnięcie dotychczasowych struktur, dokonuje się gdzieś między, w grze, bardziej dzięki zbiegom okoliczności i chaotycznym, karnawałowym transgresjom niż dzięki świadomym decyzjom i wyborom czy tym bardziej dzięki walce ukierunkowanej jakąkolwiek ideologią. I to ten właśnie proces swoista ślepota Matchka najlepiej ilustruje. Równie dobrej analizy tego procesu Laroui dostarczył w swojej powieści z 2017 roku, L'insoumise de la Porte de Flandre [Niepodległa spod Porte de Flandre $]^{12}$, obierając temat z pozoru znacznie poważniejszy, zaanonsowany już od początku szyldem islamskiego rzeźnika w brukselskiej dzielnicy Molenbeek. Bez krwawego mordu, jaki od pierwszych stron powieści zapowiada obecność masarskiego tasaka, ostatecznie się nie obejdzie, ale przypieczętuje on nie triumf fundamentalistycznej przemocy, lecz przeciwnie, właśnie rozprzęgnięcie, rozpłynięcie się granicy, koniec Molenbeek jako getta - i więcej, wyzwolenie kobiety, koniec interakcji, w której stronami była twarz i pupa. Interesujące byłoby tu skądinąd zestawienie dwóch kluczowych powieści napisanych po francusku przez Marokańczyków: Les Boucs [Kozłów] Drissa

9 Por. m.in. E. Łukaszyk Od podległości do horyzontalnego diagramu relacji. Studium procesów transkolonialnych, Debaty Artes Liberales, t. X: Perspektywy postkolonializmu w Polsce, Polska w perspektywie postkolonialnej, red. J. Kieniewicz, Wydział "Artes Liberales", Warszawa 2016, s. $87-103$.

Por. B. Ashcroft, G. Griffiths, H. Tiffin The Empire Writes Back: Theory and Practice in Post-Colonial Literatures, , Routledge, London-New York 1993.

11 Por. m.in. W.D. Mignolo The Darker Side of Western Modernity. Global Futures, Decolonial Options, Duke University Press, Durham-London 2011. 
Chraïbiego ${ }^{13}$ i tej nowej książki Larouiego. O ile w 1955 roku, momencie przełomu kolonialnych i postkolonialnych czasów, zbiorowy mord popełniony przez grupę północnoafrykańskich robotników pełnił funkcję założycielską, ustanawiał wspólnotę, jej miano i jej problem, o tyle całkowicie indywidualny i prywatny mord Fawziego w roku 2017 przypieczętowuje - wbrew jakże powszechnym obawom - jej ostateczny koniec, wyczerpanie i rozpad, delinking niemający już żadnych dekolonialnych podtekstów.

Podobnie jak Les noces fabuleuses..., również nowa powieść Larouiego niesie karnawałowy potencjał, nawet jeśli jej humor obleka się w czerń. Podobnie zresztą jak główna bohaterka, Fati, błyskotliwa studentka brukselskiej wszechnicy, która niespodziewanie sprawia sobie nikab. Paraduje w nim po Brukseli, mylona przez Chińczyków z saudyjską turystką i karana przez policję kolejnymi mandatami za zakrywanie twarzy. Jednak czarna burka jest przebraniem, pod którym kryje się transgresyjny zamiar. Wydostawszy się z dzielnicy Molenbeek spowita w woale, Fati zmienia ubiór na europejski w sublokatorskim mieszkaniu w centrum, by następnie skierować się do erotycznego przybytku, w którym pracuje jako striptizerka. Cała ta gra jest formą poszukiwania siebie i ukazuje podwójną niewidzialność kobiecej twarzy: zarówno wówczas, gdy jest zakryta muzułmańską zasłoną, jak i wówczas, gdy tańcząc w erotycznej masce Fati wypina się wprost w przyklejone do szyb w kabinach twarze swoich klientów. Podobnie jak Matchek natrafiający na swą młodą żonę na drabinie, bywalcy klubu wchodzą w zupełnie antyLévinasowską relację z Drugim/Drugą, który/a objawia się jako Pupa.

W przyjętej przez pisarza konwencji czarnego humoru, przebraną dziewczynę ktoś jednak śledzi, a śladami tego prześladowcy podąża z kolei dziennikarz detektyw, ze zdumieniem odkrywający tajemnicę, którą kwituje kalamburem o pięknym ciele muzułmańskiego kruka („le corps beau du corbeau”). Odkrycie wstrząsa jednak o wiele bardziej pierwszym prześladowcą. Jest nim Fawzi, młody Arab, który upatrzył sobie pobożną dziewczynę jako przyszłą żonę i natychmiast poczuł się jej jedynym prawowitym właścicielem. Nic więc dziwnego, że porwawszy nóż ze sklepu mięsnego swego brata, masakruje obfite ciało właściciela sex-klubu, uszkodziwszy po drodze manekin, na którym prezentowano wykwintny, czerwony biustonosz. Wreszcie ciało zastrzelonego na miejscu Fawziego przez wiele godzin leży na brukselskiej ulicy, podczas gdy policja nieśpiesznie dokonuje stosownej ekspertyzy pirotechnicznej, spodziewając się, że zamachowiec nie działał w pojedynkę, toteż

Por. D. Chraïbi Les Boucs, Denoël, Paris 1955. 
trup może mieć na sobie ładunek wybuchowy. Fati, której nie skojarzono z zabójstwem mimo zeznań dziennikarza, przysłuchuje się uczonym debatom, jakie zorganizowano w obliczu wydarzenia. Laroui przytacza verbatim wyjątki wzięte z pism zajmujących się islamem intelektualistów, z Rachidem Benzine na czele. Ten młody myśliciel zdaje się zajmować już dzisiaj niepodzielnie niegdysiejsze miejsce Tarika Ramadana. Ale ustępujący profesor Oksfordu został zresztą również odmalowany w satyrycznym świetle na kartach tej powieści, łącznie z wykwintem swych garniturów.

Tymczasem w Molenbeek pod wpływem szoku umiera także ojciec Fati. W ostatecznym rozrachunku okazuje się więc, że dziewczyna pozbyła się jednocześnie trzech instancji patriarchalnej władzy: ojca, niedoszłego męża i sutenera. Wyprawiwszy więc rodzicielską trumnę w powrotną drogę do wioski w górach Rifu, zdaje klucze właścicielowi mieszkania i opuszcza Molenbeek na zawsze. Oczywiście już bez nikabu.

Ubrania odgrywają w tej powieści nieco podobną rolę, jak marokańska kuchnia w noweli o weselu Polaka. Są nośnikiem tożsamości i kultury, ale niekiedy dają się też użyć w tak przewrotny sposób, że koniec końców powalają się od kultury uwolnić. Ubranie osadza w określonej lokalizacji, przypisuje do kulturowego scenariusza; zmiana ubrania, przebieranie się i rozbieranie pozwala się z tego miejsca wymknąć, krążyć między, wybić się na autentyczność, dojść do indywidualnej prawdy. Tarik Ramadan, przedstawiony w powieści jako „zasponsorowany przez Armaniego", a więc obleczony w strój, który zarazem ucieleśnia niewidzianą kontrolę, jest „podkupionym”, nieautentycznym i w gruncie rzeczy już przegranym figurantem, obsadzonym w reżyserowanym przez kogo innego programie na temat islamu i muzułmanów. Z pozoru taką samą funkcję mógłby pełnić nikab Fati, narzucone jej narzędzie męskiej i ogólniej, społecznej kontroli, w której ciało muzułmańskiej kobiety zostaje jej odebrane i oddane na wyłączność komu innemu. Tymczasem właśnie pod nikabem Fati staje się depozytariuszką samej siebie. Przywdziewa woale i obnaża się jako autonomiczny podmiot zdolny do poruszania się między obiema skrajnościami. Wystawiając pupę na spotkania z męską twarzą, niepostrzeżenie zmienia się z ofiary $\mathrm{w}$ bezczelną triumfatorkę pozostającą na scenie usłanej trupami. Z zamiarem kontynuacji studiów uniwersyteckich i być może podjęcia kariery politycznej. Powieściowa Bruksela obwieszona jest przecież plakatami wyborczymi, na których widnieją twarze - i wiele $\mathrm{z}$ nich to twarze marokańskich kobiet, takich jak Fati.

Wydaje się więc, że postkolonialna lektura Larouiego przeistoczyła się niespostrzeżenie w lekturę genderową. Z kolei Molenbeek a sprawa polska 
to potencjalne ujęcie konfrontujące rozdęty na wietrze nikab i czarne parasolki rodzimych protestów. W obu przypadkach chodzi bowiem o ciała odebrane kobietom i oddane pod zewnętrzną wobec nich kontrolę, o pojawienie się kogoś lub czegoś, co w nich pokłada swój honor i żąda oczyszczenia go przez ofiarę. Co ciekawe, właśnie słowo oczyszczenie pojawiło się - jako słowo polskie - wplecione w tok francuskojęzycznej narracji Larouiego w Les noces fabuleuses...: „On dirait un rite de... comment dit-on?... oczyszczenie...” ${ }^{\text {. }}$. Co prawda odnosiło się tam do kąpieli panny młodej w hammamie; a jednak właśnie ta potrzeba puryfikacji kobiecego ciała była czymś, co z obcego rytuału Matchek zrozumiał najlepiej, co najbardziej pragnął ujrzeć na własne oczy i co musiało wybrzmieć w jego własnym języku. To właśnie pojedyncze słowo, zapamiętane i zapisane przez marokańskiego interlokutora, powróciło jako przesyłka zwrotna. Czy do końca przypadkiem?

Tak czy owak, nie tyle zamiast, co ponad możliwymi lekturami, wynikłymi z przyjętych do tej pory założeń teoretycznych, do zapostulowania pozostaje transkulturowa lektura Larouiego. Zgodnie z definicją aspiracji transkulturowej jako dążenia do radykalnego wycofania się jednostki z kulturowych paradygmatów czy też jej opróżnienia z wyuczonych i zautomatyzowanych reakcji, jaką starałam się ostatnio zarysować ${ }^{15}$, Laroui przedstawia w swoim pisarstwie nie tyle ludzi, którzy znaleźli się, z racji narzuconych lub wybranych okoliczności biograficznych, na pograniczu kultur, co takich, którzy dokonali świadomego „skoku z pokładu”, pragnąc znaleźć się w nieokreślonym żywiole otaczającym i oddzielającym kultury jako ustrukturyzowane systemy znaczeń lub paradygmatyczne, prefabrykowane zbiory dopuszczalnych działań i reakcji. Zupełnym przeciwieństwem transkulturowego poszukiwania autentyczności i dostępu do działań spontanicznych jest z kolei Fawzi, który, odkrywszy prawdę o przebranej w nikab dziewczynie, natychmiast wpada, niczym w koleinę, w śródziemnomorski paradygmat męskiego honoru i zarazem makabryczny stereotyp Araba ganiającego po zaułkach z rzeźnickim nożem. Tych kulturowych paradygmatów jest jednak w powieści więcej i nie mają one bynajmniej związku wyłącznie z muzułmanami. Jednym z nich jest obraz Marata zasztyletowanego w kąpieli. Z kolei kobiece poszukiwanie drogi do własnego ciała przebiega wśród kamiennych aktów zdobiących parki i ulice oraz belgijskich czekoladek, na których widnieje Lady Godiva.

14 F. Laroui, Les noces fabuleuses..., S. 35.

15 Por. E. Łukaszyk Humanistyka, która nadchodzi. W poszukiwaniu kondycji transkulturowej, DiG, Warszawa 2018. 
Nie chodzi zatem o prostą zmianę paradygmatu na inny, o wymknięcie się z jednej kultury, aby znaleźć się w drugiej. Cóż w istocie zyskałaby Fati, gdyby porzuciwszy swoją muzułmańską skromność zyskała stałą pracę na etacie zachodniej striptizerki? Prawdziwa wolność nie leży po żadnej ze stron, ale między; wyzwalająca jest swoboda ruchu między kulturami, przekraczania wymagań narzucanych przez każdą z nich z osobna. Co więcej, tylko odrzucenie jednoznaczności przypisania do którejkolwiek ze stron pozwala odkryć ożywczą świeżość i prawdę leżącą u pierwszych źródeł, sprzed podziału na kultury jako odrębne linie tradycji. Spotkanie z Twarzą w L'insoumise de la Porte de Flandre dokonuje się za pośrednictwem malowidła pochodzącego z Brukseli XVII-wiecznego malarza, Philippe'a de Champaigne, przedstawiającego Chrystusa między uczonymi w Piśmie. Nie oznacza jednak wyboru chrześcijaństwa jako antidotum na przerażające nauki marokańskiego imama o piekle; wchodzi tu raczej w grę odkrycie jedności piekła, którym straszono, zaledwie jedno czy dwa pokolenia wstecz, także niderlandzkie kobiety. Ale malowidło prefiguruje jednocześnie pozycję samej bohaterki między współczesnymi uczonymi w Piśmie, z zaopatrzonym u Armaniego Tarikiem Ramadanem włącznie.

Nawiasem mówiąc, w swoim ironicznym rozliczeniu z intelektualistami muzułmańskimi Laroui wzmiankuje kwestię sufizmu, pomysł przekierowania spraw w stronę islamu mistycznego, co mogłoby odsunąć punkt ciężkości od formalistycznych i teokratycznych pozycji fundamentalizmu. Kwestia ta, odgrywająca dużą rolę w mojej własnej, transkulturowej wizji, przygasła, jak się wydaje, wraz ze śmiercią jej głównego orędownika, jakim był tunezyjski myśliciel Abdelwahab Meddeb. U Larouiego na scenie ostaje się przede wszystkim Benzine, potraktowany w powieści najłagodniej i przedstawiony z niejaką rewerencją jako spadkobierca Muhammada Arkouna. Transkulturowa przyszłość muzułmańskiej Europy, jeśli chcielibyśmy o niej wspomnieć w tym miejscu, wydaje się więc zrastać, przynajmniej w powieściowym ujęciu, raczej z powszechnym intelektem Awerroesa niż z mistycznym wglądem Ibn Arabiego. Mimo to bohaterka przywołuje w myślach postać Rabii al-Adawiyyi, mistyczki z pierwszych wieków islamu, być może w poszukiwaniu tego zwycięskiego kobiecego kontrapunktu, o jaki najwyraźniej tu chodzi.

Można byłoby oponować, że to właśnie wyłamanie się z kulturowego zaszeregowania, złamanie jednoznaczności tożsamościowego podziału, odkrycie gry przebierającej i obnażającej się bohaterki prowokuje krwawą rozprawę na brukselskiej ulicy. A jednak to kobieta jest jedyną, która z tej konfrontacji wychodzi bez szwanku; jej żywotne ciało wygrywa partię rozgrywaną przeciw 
kulturze niczym w szachowym pojedynku rycerza ze śmiercią. To zwycięstwo, które w zasadzie powinno być niemożliwe. Wyzwolenie od kulturowych służebności, którym właśnie kobieta podlega w pierwszej kolejności rysuje się jednak jako konieczność w sytuacji spiętrzenia sprzeczności, jakie podminowuje jednostkowe istnienie. Fati sprzed zwycięstwa nad kulturą przyrównywała samą siebie do matrioszki, w której zamknięte były kolejno coraz głębiej skrywane tożsamości. Do scalenia prawdy o sobie dochodzi wyłącznie przez anulowanie podziału rzutowanego w głąb jednostkowej egzystencji przez zewnętrzne, kulturowe warunki, prawdy odziedziczone, wyuczone, zasłyszane od uczonych w Piśmie: od imama, na uczelni, na spotkaniach z intelektualistami. Przekładały się one zarazem na niewidzialne rysy w przestrzeni miasta, dzielące Molenbeek od Centrum.

Być może podobne scalenie osiągnął też Matchek dokonując podwójnego wyjścia: po pierwsze z ponurej rzeczywistości własnego kraju, po drugie z ciasnego kręgu Polaków „na kontrakcie” w marokańskiej kopalni fosfatów, nawet jeśli oglądamy go w komicznej roli, gdy usiłuje tańczyć w prującej się, poplamionej dżellabie podczas parodii swojego własnego wesela. Jego aż nazbyt widoczna niekompetencja wobec świata kontrastuje z erudycją Fati, czytającej więcej od „prawdziwych” Belgów, bywalczyni muzeów, nieopuszczającej ani jednego spotkania z intelektualistami. Ale i ona ostatecznie parodiuje samą siebie, przywdziewając nikab jako przebranie, czyniąc z tożsamości maskaradę. Za każdym razem stawką jest triumf wielokształtności i plastyczności życia nad stagnacją i wpisanym w skostniałe paradygmaty kulturowej transmisji zniewoleniem. 


\section{Abstract}

\section{Ewa Łukaszyk}

LE STUDIUM LOIRE VALLEY INSTITUTE FOR ADVANCED STUDIES

Khouribga and the Polish Cause: The Victory of Life over Culture in Fouad Laroui's Work

Beginning with a presentation of Fouad Laroui's novella Les noces fabuleuses du Polonais, Łukaszyk outlines its potential in Polish post-colonial studies understood as an analysis of Poles' participation in the Eastern Bloc's neo-colonial project. She essentially proposes athreefold reading drawing on post-colonial theory, gender and transcultural studies. Juxtaposing the novella with the novel L'insoumise de la Porte de Flandre Łukaszyk is able to describe Laroui's message in more depth. The writer not only tackles Morocco's neocolonial experience, characterized by the arrival of Polish 'contractual' specialists. Above all he invites readers to destabilize their identity and to liberate themselves from the corset of mental automatisms - a corset acquired whenever culturally transmitted paradigms are treated as an absolute.

\section{Keywords}

Fouad Laroui, Poles in Morocco, post-colonialism, gender, transculture 